\title{
IJCIT
}

(Indonesian Journal on Computer and Information Technology) Journal Homepage: http://ejournal.bsi.ac.id/ejurnal/index.php/ijcit

\section{Sistem Informasi Pelayanan Administrasi Berbasis Web Pada LPK Kurnia Dewi Kabupaten Tasikmalaya}

\author{
Bambang Kelana Simpony ${ }^{1}$, Anggi Anggara ${ }^{2}$, Deddy Supriadi ${ }^{3}$, A Gunawan ${ }^{4}$ \\ ${ }^{1,2,3}$ Sistem Informasi, Universitas Bina Sarana Informatika \\ Tasikmalaya, Indonesia \\ e-mail: bambang.bky@bsi.ac.id ${ }^{1}$, anggiang1406@bsi.ac.id ${ }^{2}$, deddy.dys@bsi.ac.id ${ }^{3}$ \\ ${ }^{4}$ Ilmu Komputer, Universitas Bina Sarana Informatika \\ Sukabumi, Indonesia \\ e-mail: a.gunawan.agn@bsi.ac.id
}

\begin{abstract}
A B S T R A K
Teknologi informasi sangatlah penting bagi suatu perusahaan atau lembaga, baik dalam hal promosi atau pengolahan data administrasi. LPK Kurnia Dewi merupakan perusahaan yang bergerak dibidang jasa dengan memberikan pendidikan dan pelatihan kursus mengemudi mobil. Akan tetapi, sistem pembayaran, pendaftaran, dan promosi pada LPK Kurnia Dewi masih terdapat kendala. Untuk sistem pelayanan sudah menggunakan android namun untuk admin nya masih berbasis web, serta belum terkomputerisasinya sistem pelayanan pendaftaran serta sistem keuangan. Tujuan dari penelitian ini adalah membuat Sistem Informasi Pelayanan Administrasi Berbasis Web untuk mempermudah dalam pengolahan pembayaran admin dan pendaftaran siswa melalui website, serta laporan keuangan lebih terperinci pada lembaga tersebut. Metode yang digunakan dalam pembuatan program aplikasi ini adalah metode waterfall yang terbagi menjadi lima tahapan. Hasil dari penelitian ini adalah terciptanya program pelayanan administrasi berbasis web yang dapat membantu perusahaan dalam mengelola pendaftaran, pembayaran, penjadwalan, absensi pelatihan dan sertifikat pelatihan siswa, serta resiko kehilangan data dapat di minimalisir.
\end{abstract}

Kata Kunci : administrasi, berbasis web, sistem informasi.

\begin{abstract}
A B S TR A C T S
Information technology is very important for a company or institution, both in terms of promotion or administrative data processing. LPK Kurnia Dewi is a company engaged in services by providing education and training in car driving courses. However, the payment system, registration, and promotion of LPK Kurnia Dewi still has obstacles. The service system uses Android, but the admin is still web-based, and the registration service system and financial system are not yet computerized. The purpose of this study is to create a Web-Based Administration Information Service System to facilitate the processing of admin payments and student registration through the website, as well as more detailed financial reports at the institution. The method used in making this application program is the waterfall method which is divided into five stages. The results of this study are the creation of a web-based administrative service program that can help companies manage registration, payment, scheduling, attendance training and student training certificates, and the risk of data loss can be minimized.
\end{abstract}

Keywords: administrative, information systems, web based. 


\section{PENDAHULUAN}

Menurut Sutabri dalam (Paryanta, Sutariyani, \& Susilowati, 2017) Sistem informasi adalah suatu sistem didalam suatu organisasi yang mempertemukan kebutuhan pengolahan transaksi harian yang mendukung fungsi organisasi yang bersifat manajerial dalam kegiatan strategi dari suatu organisasi untuk dapat menyediakan kepada pihak luar tertentu dengan laporan-laporan yang diperlukan.

Menurut Moh. Rifai dalam (Achmadi Prasita Nugroho, Bambang Hindrajid, Anang Aris Widodo, 2016) administrasi adalah keseluruhan proses yang mempergunakan dan mengikut sertakan Semua sumber potensi yang tersedia dan yang sesuai, baik personal maupun material, dalam usaha untuk mencapai bersama suatu tujuan secara efektif dan efisien.

Sistem informasi administrasi pada suatu instansi, perusahaan, maupun lembaga adalah salah satu komponen penting. Pendaftaran, pembayaran, penjadwalan, dan laporan keuangan adalah salah satu bagian dari administrasi. Pada era digital saat ini tentunya sistem administrasi pada suatu lembaga harusnya telah terkomputerisasi demi mempermudah, mempercepat pelayanan, serta mengahasilkan laporan yang terperinci.

Menurut (Marisa, 2017) Website dapat diartikan sebagai kumpulan halaman-halaman yang digunakan untuk mempublikasikan informasi berupa teks, gambar dan program multimedia lainnya berupa animasi (gambar gerak, tulisan gerak), suara dan atau gabungan dari semuanya itu baik yang bersifat statis maupun dinamis yang membentuk suatu rangkaian bangunan yang saling terkait antara satu halaman dengan halaman yang lain yang sering disebut sebagai hyperlink.

Menurut Fathansyah dalam (Prayitno \& Safitri, 2013) Server Web (Web Server) merujuk pada perangkat keras (server) dan perangkat lunak yang menyediakan layanan akses kepada pengguna melalui protokol komunikasi HTTP ataupun variannya (seperti FTP dan HTTPS) atas berkas-berkas yang terdapat pada suatu URL ke pemakai.

Menurut Undang-Undang Nomor 20 Tahun 2003 Tentang Sistem Pendidikan Nasional (USPN), pasal 26 ayat (4) dalam (Achmadi Prasita Nugroho, Bambang Hindrajid, Anang Aris Widodo, 2016) dinyatakan bahwa lembaga pelatihan merupakan satuan pendidikan nonformal, di samping satuan pendidikan lainnya seperti kursus, kelompok belajar, majelis ta'lim, kelompok bermain, taman penitipan anak, pusat kegiatan belajar masyarakat, serta satuan pendidikan yang sejenis. Yang termasuk ke dalam satuan pendidikan yang sejenis antara lain adalah panti penyuluhan, magang, bimbingan belajar, kepramukaan, pondok pesantren tradisional (salafiyah), padepokan, dan sanggar. Pelatihan dapat dilakukan dalam jenis dan ruang lingkup pendidikan nonfonnal. Jenis pendidikan mencakup pendidikan umum, pendidikan keagamaan, pendidikan jabatan kerja, pendidikan kedinasan, dan pendidikan kejuruan (Peraturan Pemerintah No. 73 Tahun 1991). Ruang lingkup pendidikan nonfonnal adalah pendidikan anak usia dini, pendidikan keaksaraan, pendidikan kesetaraan, pendidikan kecapakan hidup, pendidikan kepemudaan, pendidikan pemberdayaan perempuan, pendidikan usia lanjut, dan pendidikan melalui media masa.

LPK Kurnia Dewi yang beralamat di jalan Raya Barat Ciputri, Singaparna, Kabupaten Tasikmalaya merupakan lembaga yang bergerak dibidang jasa dengan memberikan pendidikan dan pelatihan kursus mengemudi mobil. Sebelumnya sudah ada sistem pelayanan yang berbasis android, namun untuk adminnya masih menggunakan sistem berbasis web dan kekurangan pada aplikasi tersebut adalah belum terkomputerisasinya sistem pelayanan pendaftaran melalui admin dan sistem keuangannya belum terkomputerisasi. Masalah yang timbul dari hasil penelitian pada sistem berjalan di LPK Kurnia Dewi ini adalah tidak terkomputerisasinya sistem administrasi, baik itu pendaftaran, pembayaran, penjadwalan, dan laporan keuangan. Sehingga dalam proses administrasi kurang efisien.

Dari beberapa masalah yang penyusun sebutkan diatas, maka rumusan masalah pada Penelitian ini adalah bagaimana membuat suatu program administrasi berbasis website yang dapat mempermudah pelayanan administrasi perusahaan.

\section{METODE PENELITIAN}

Metode penelitian yang digunakan pada pengembangan perangkat lunak ini mengunakan model waterfall, yang memiliki pendekatan alur hidup perangkat lunak secara terurut dimulai dari analisis, desain, pengkodean, pengujian dan tahap pendukung (support) berikut penjelasan 
dari setiap tahapan menurut (A.S \& Shalahuddin, 2014):

a. Analisis

Tahapan ini akan dilakukan proses pengumpulan kebutuhan yang akan digunakan oleh user serta mendokumentasikan semua spesifikasi kebutuhan tersebut.

b. Desain

Memiliki beberapa desain tahapan dalam membuat program diantaranya struktur data, arsitektur perangkat lunak, representasi antarmuka, serta prosedur pengkodean. Setiap desain akan didokumentasikan. Pembuatan LRS (Logical Record Structure).

c. Pengkodean

Desain yang sudah dibuat diatas selanjutnya ditranslasikan ke dalam program perangkat lunak. Hasilnya adalah program komputer yang sesuai dengan desain yang telah dibuat sebelumnya.

d. Pengujian

Tahap ini memastikan bahwa setiap bagian perangkat lunak berjalan dari segi logika dan fungsionalitas nya serta memastikan keluaran yang dihasilkan sesuai dengan yang diinginkan. Serta untuk meminimalisir kesalahan (error) dari program.

e. Pendukung (support)

Ditahap ini tidak menutup kemungkinan mengulangi proses pengembangan mulai dari analisis dikarenakan adanya perubahan yang diakibatkan oleh kesalahan yang muncul dan tidak terdeteksi sebelumnya saat tahap pengujian.

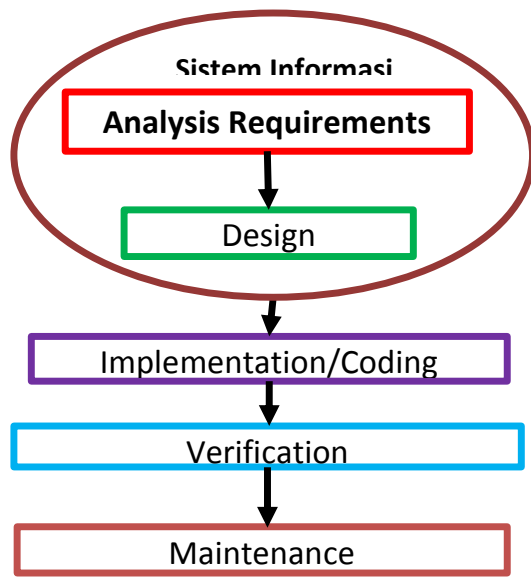

Gambar 1. Tahapan Penelitian

\section{HASIL DAN PEMBAHASAN}

Hasil dan pembahasan pada peneltian program sistem informasi administrasi berbasis web dimulai dari analisa kebutuhan pengguna dan sistem, rancangan sistem dan implementasi.

\subsection{Analisa Kebutuhan}

a. Super Admin

Super admin dapat melakukan login, kemudian dapat mengelola data admin dan mengelola data instruktur. Selanjutnya Super Admin dapat mengelola data siswa, mengelola pembayaran. dan mencetak laporan.

b. Admin

Admin dapat melakukan login, kemudian dapat mengelola data siswa, jadwal latihan, mengelola pembayaran serta mencetak laporan.

c. Instruktur Instruktur dapat melakukan login, kemudian mengambil jadwal mengajar dan memberikan sertifikat hasil pelatihan. Kemudian Instuktur juga dapat melakukan absen siswa setiap pertemuan.

d. Siswa

Siswa bisa melakukan pendaftaran baik secara online atau daftar melalui admin, siswa dapat melakukan login, setelah melakukan pendaftaran, selanjutnya siswa memilih paket pelatihan dan melihat jadwal pelatihan. Kemudian siswa dapat melihat status pembayaran. mencetak kartu latihan siswa, dan mencetak hasil belajar berupa sertifikat.

\subsection{Rancangan Sistem}

Rancangan sistem dalam penelitian ini terdiri dari rancangan basis data, pengkodean, dan stuktur navigasi.

\section{A. Rancangan Basis Data}

Basis data dirancangan menggunakan model Logical Record Structure (LRS) yang dapat dilihat pada gambar 2 . 


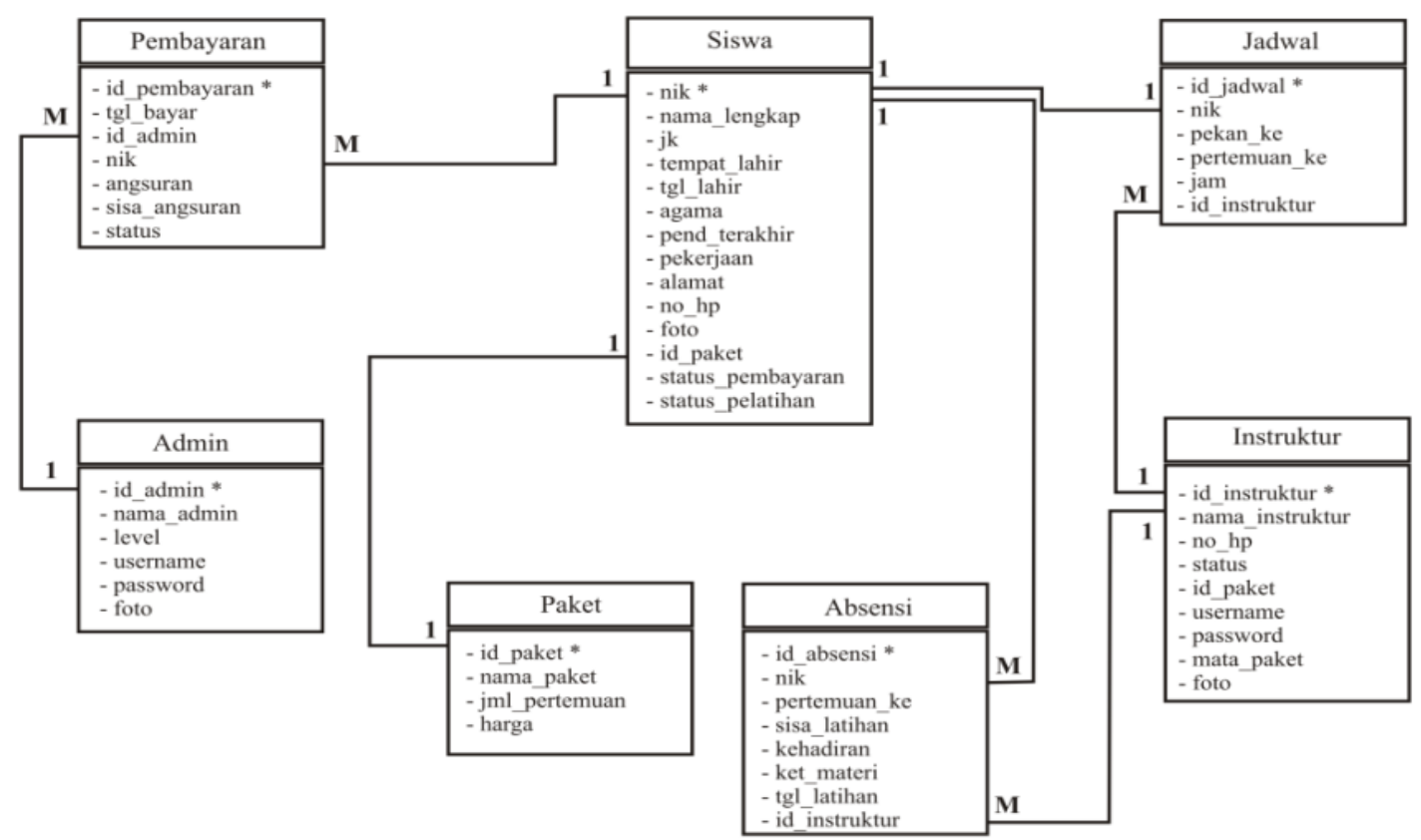

Gambar 2. Logical Record Stucture

\section{B. Pengkodean}

Kode yang dibutuhkan dalam program sistem informasi administrasi berbasis web yaitu kode ID Admin, ID Instruktur, ID Paket, ID Absensi, dan ID Pembayaran.

1) ID Admin

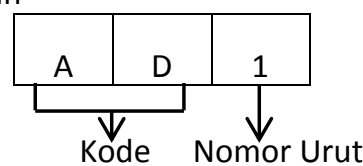

2. ID Instruktur

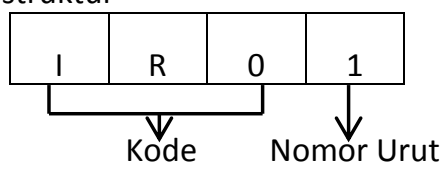

3. ID Paket

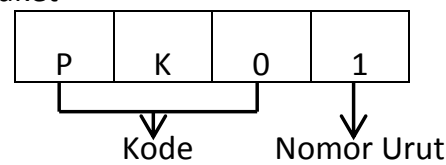

4. ID Absensi

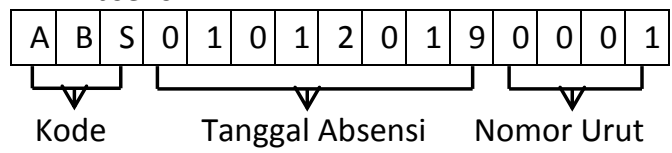

5. ID Pembayaran

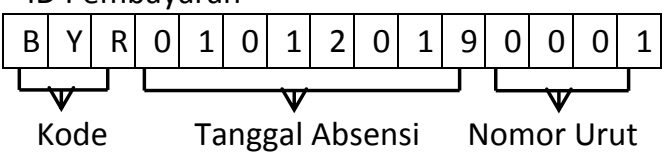

\section{Stuktur Navigasi}

Terdapat beberapa stuktur navigasi dalam program sistem informasi administrasi berbasis web, diantaranya super admin, admin, instruktur, siswa, dan pengunjung.

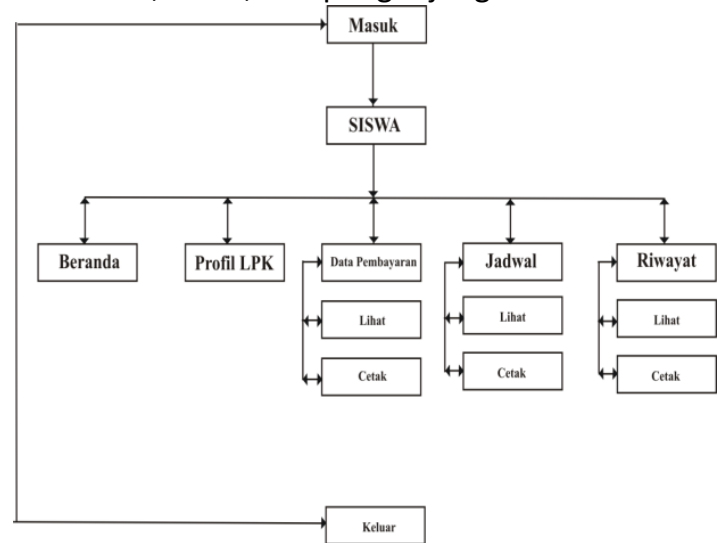

Gambar 6. Struktur Navigasi Siswa

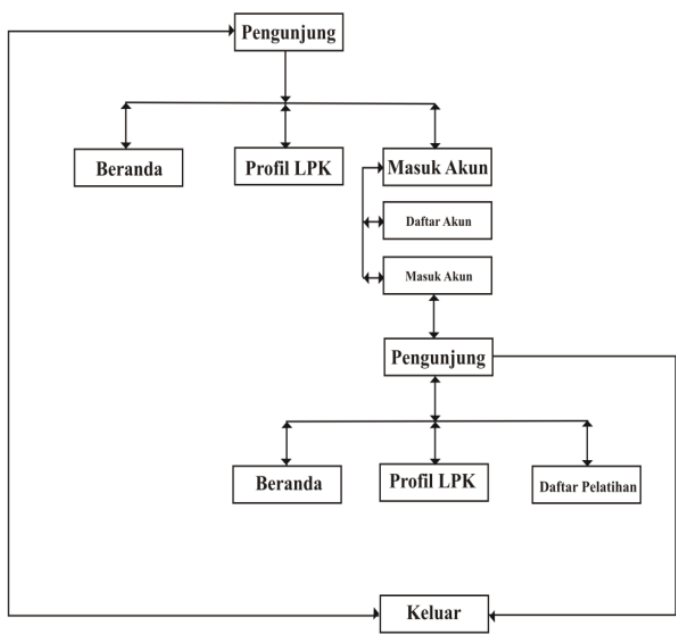

Gambar 7. Struktur Navigasi Pengunjung 


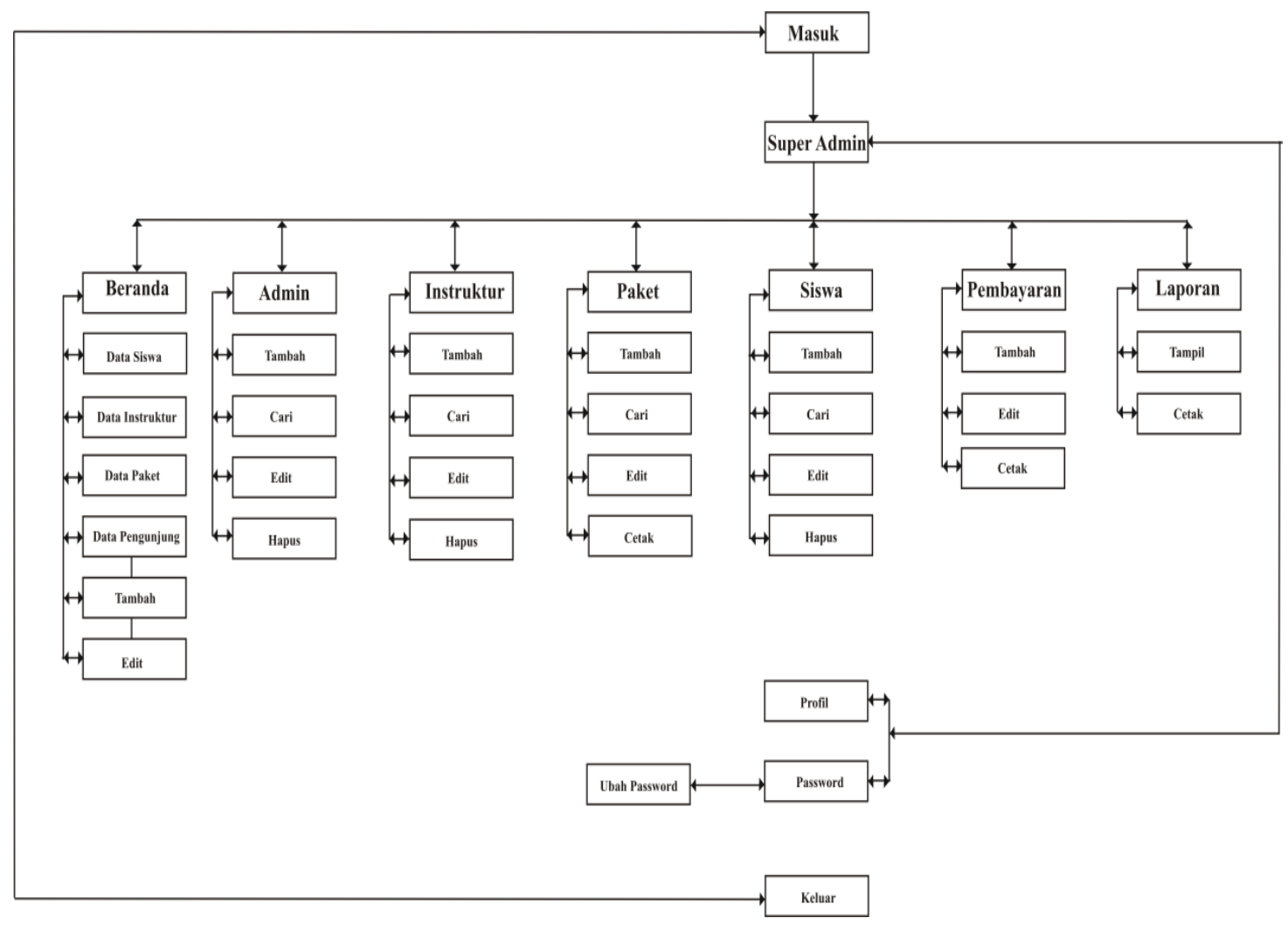

Gambar 3. Stuktur Navigasi Super Admin

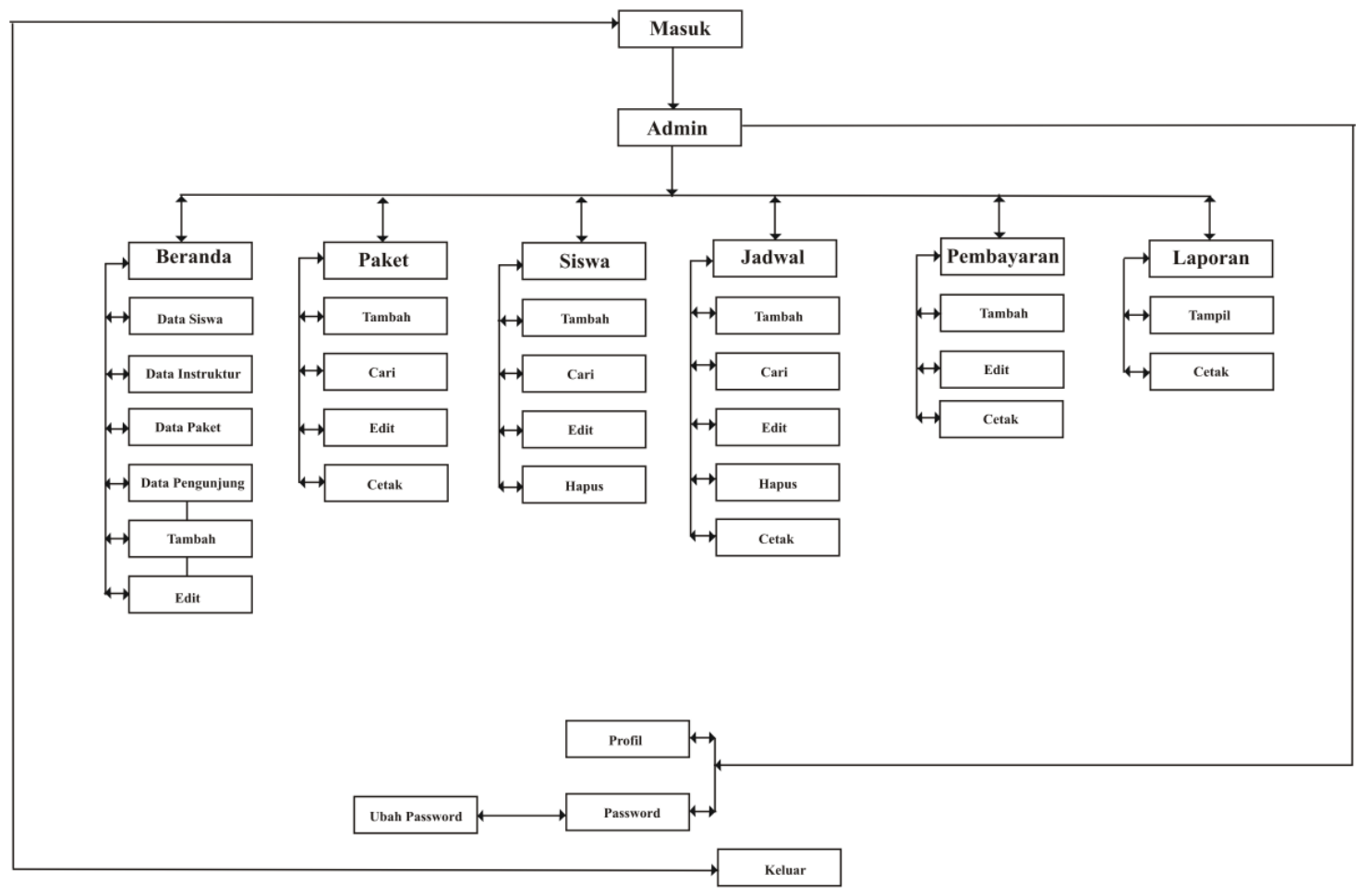

Gambar 4. Struktur Navigasi Admin 


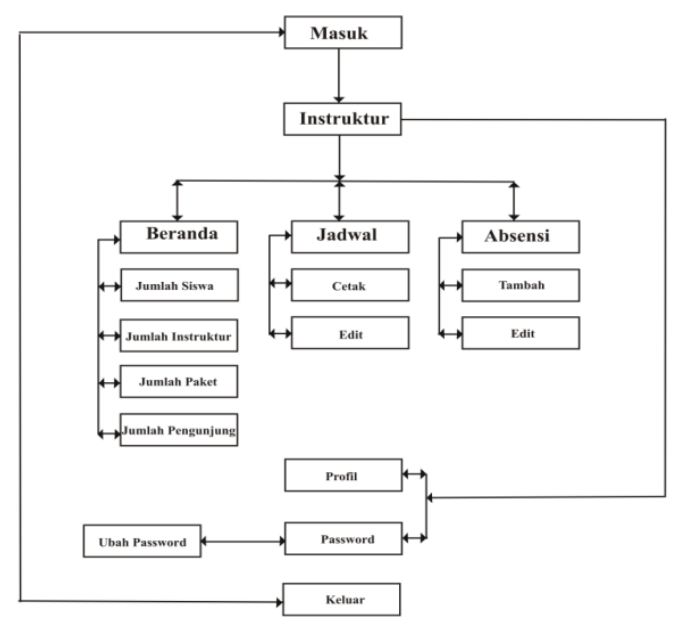

Gambar 5. Struktur Navigasi Instruktur

\subsection{Implementasi}

Implementasi antar muka dalam program sistem informasi administrasi berbasis web tampak pada gambar 8-gambar 20.

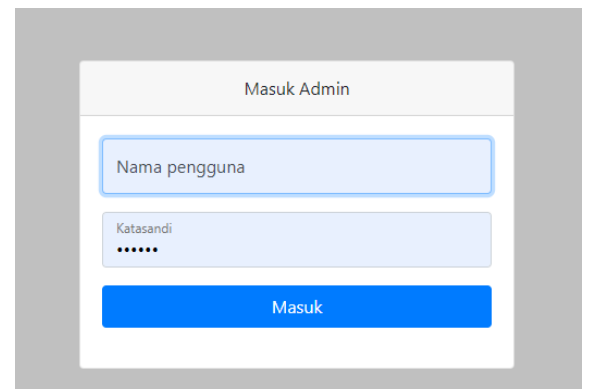

Gambar 8. Halaman Login

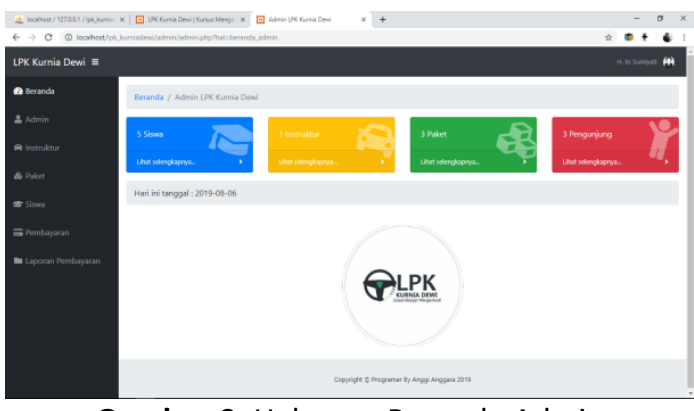

Gambar 9. Halaman Beranda Admin

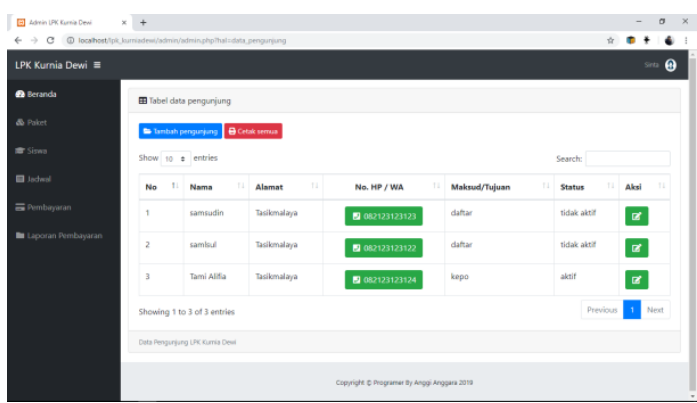

Gambar 10. Halaman Data Pengunjung

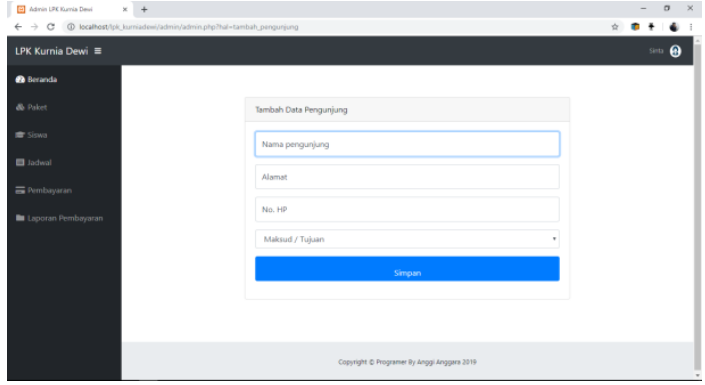

Gambar 11. Halaman Tambah Data Pengunjung

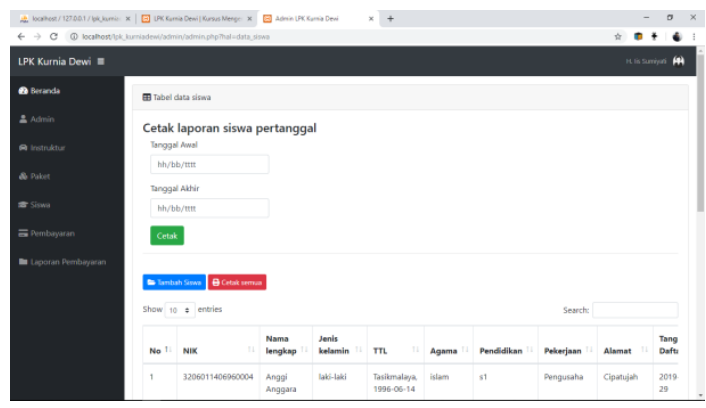

Gambar 12. Halaman Data Siswa

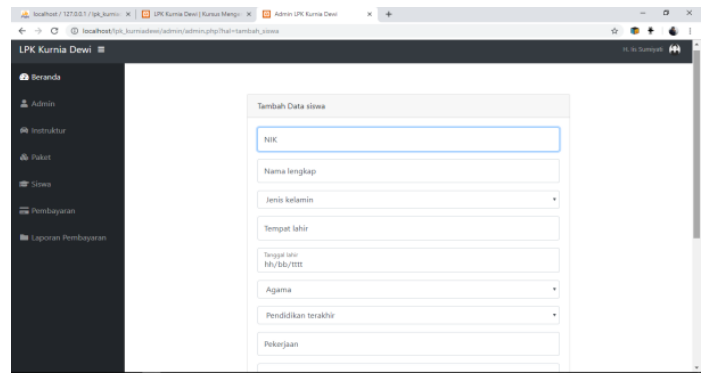

Gambar 13. Halaman Tambah Siswa

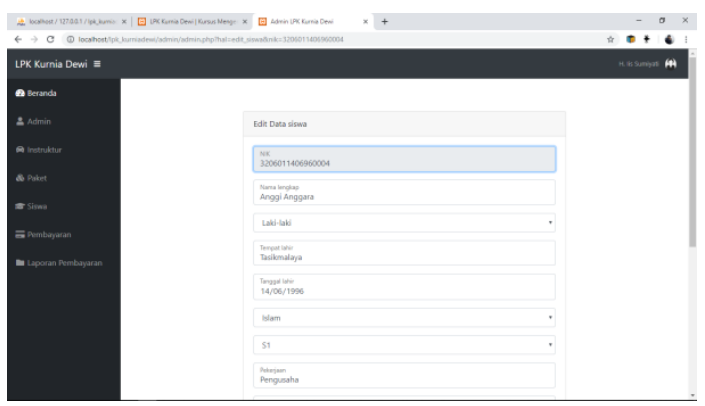

Gambar 14. Halaman Ubah Data Siswa

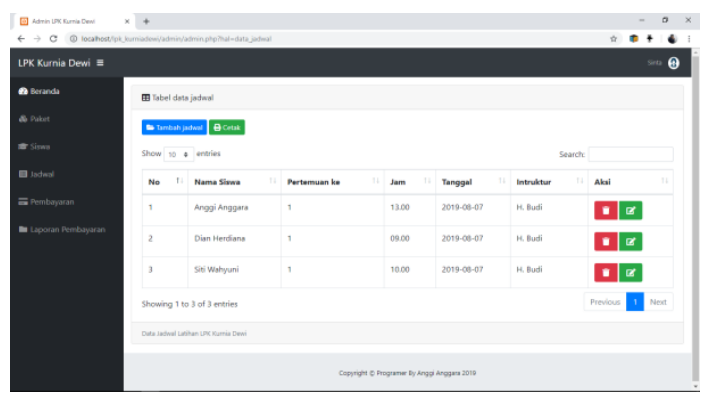

Gambar 15. Halaman Data Jadwal 


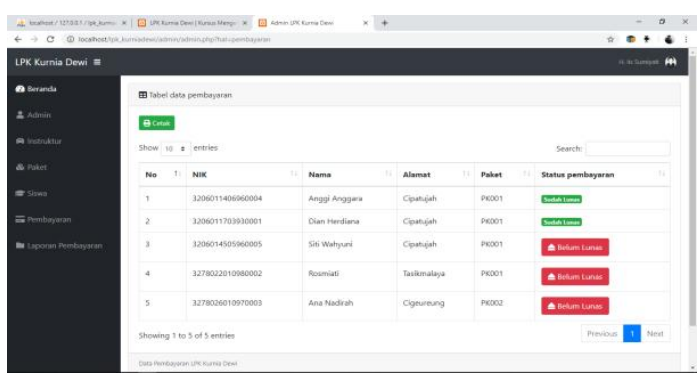

Gambar 16. Halaman Data Pembayaran

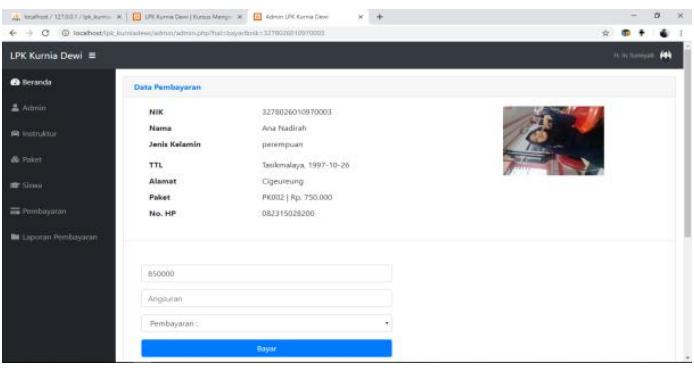

Gambar 17. Halaman Input Pembayaran

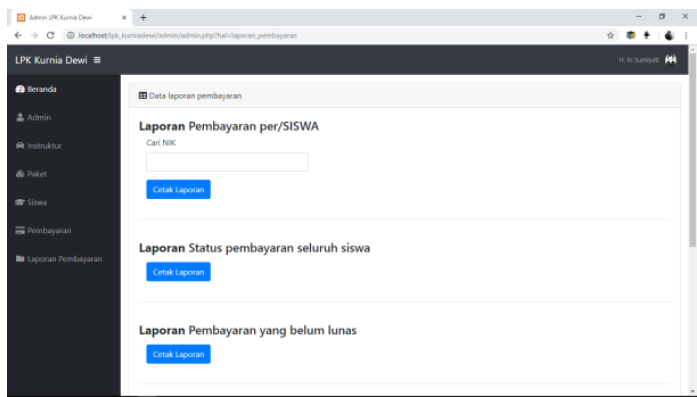

Gambar 18. Halaman Laporan Pembayaran

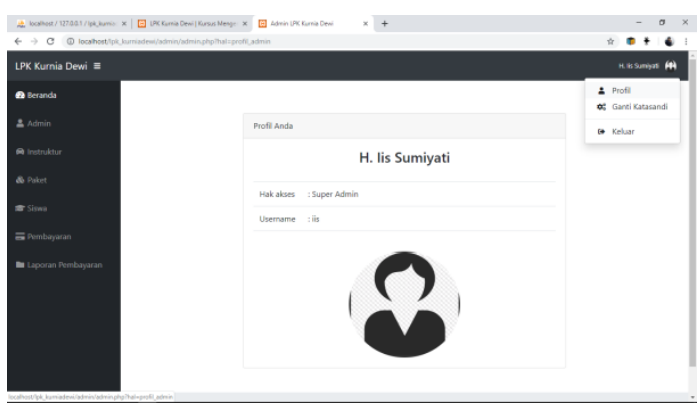

Gambar 19. Halaman Laporan Pembayaran

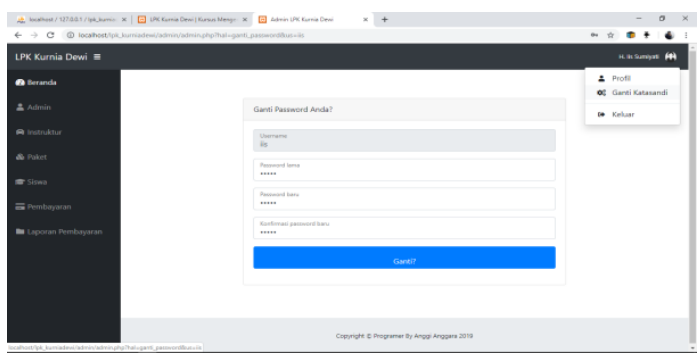

Gambar 20. Halaman Ganti Password

\section{KESIMPULAN}

Kesimpulan dari penelitian mengenai sistem informasi pengelolaan Administrasi pada LPK Kurnia Dewi berbasis website tersebut, adalah dengan dibuatkannya program berbasis website ini, membantu pengelolaan Administrasi seperti pembayaran pelatihan mengemudi dapat dikontrol dan dikelola dengan baik. Dapat mempermudah kinerja admin, karena mengurangi resiko kehilangan dan kerusakan data. Serta mempermudah dalam proses penginputan data. Proses pembuatan laporan yang mudah sehingga dapat mengefesienkan waktu. Mempermudah instruktur pelatihan dalam mengelola kehadiran siswa. Sebagai media promosi kepada masyarakat mengenai LPK Kurnia Dewi. Memudahkan masyarakat yang ingin mengikuti pelatihan mengemudi di LPK Kurnia Dewi.

\section{REFERENSI}

A.S, R., \& Shalahuddin, M. (2014). Rekayasa Perangkat Lunak Terstruktur dan Berorientasi Objek. Bandung: Informatika.

Achmadi Prasita Nugroho, Bambang Hindrajid, Anang Aris Widodo. (2016). Enterprise Sistem Administrasi Untuk Lembaga Kursus Dan Pelatihan Studi Kasus Di LKP Inka Group Pasuruan. J I M P - Jurnal Informatika Merdeka Pasuruan. https://doi.org/10.37438/jimp.v1i2.25

Marisa, F. (2017). Web Programming untuk Membangun Portal. Yogyakarta: CV Budi Utama.

Paryanta, Sutariyani, \& Susilowati, D. (2017). Sistem Informasi Administrasi Kependudukan Berbasis Web Desa Sawahan. IJSE - Indonesian Journal on Software Engineering, 3(2), 77-81. Retrieved from https://ejournal.bsi.ac.id/ejurnal/index.p $\mathrm{hp} / \mathrm{ijse} /$ article/download/2980/1929

Prayitno, A., \& Safitri, Y. (2013). Pemanfaatan Sistem Informasi Perpustakaan Digital Berbasis Website Untuk Para Penulis. IJSE - Indonesian Journal on Software Engineering Pemanfaatan. https://doi.org/10.4028/www.scientific.n et/AMR.756-759.138 